\title{
Lactation responses and amino acid utilization of dairy cows fed low-fat distillers dried grains with solubles with or without rumen-protected lysine supplementation
}

\author{
H. A. Paz ${ }^{1}$ and P. J. Kononoff ${ }^{2}$ \\ Department of Animal Science, University of Nebraska-Lincoln, Lincoln 68583
}

\begin{abstract}
The objective of this study was to evaluate the effects of feeding different amounts of low-fat distillers dried grains with solubles (DDGS) in diets with or without supplementation of rumen-protected Lys (RPL) on lactation responses and AA utilization. Eight multiparous Holstein cows averaging $188 \pm 13$ DIM were assigned to a replicated $4 \times 4$ Latin square with a $2 \times 2$ factorial arrangement of treatments. Dietary treatments were as follows: (1) 15\% low-fat DDGS, (2) $15 \%$ low-fat DDGS plus RPL, (3) 30\% low-fat DDGS, and (4) $30 \%$ low-fat DDGS plus RPL. Periods lasted $21 \mathrm{~d}$, with the last $3 \mathrm{~d}$ for data collection. Basal diets (without RPL) were formulated using the Cornell-Penn-Miner Dairy model [Cornell University (Ithaca, NY), University of Pennsylvania (Philadelphia), and the W. H. Miner Agricultural Research Institute (Chazy, NY)] to be isonitrogenous ( $16.9 \%$ crude protein) and isocaloric (2.63 $\mathrm{Mcal} / \mathrm{kg}$ ) and inclusion of low-fat DDGS increased at the expense of corn and soybean meal. Inclusion rate of low-fat DDGS and RPL supplementation had no effect on dry matter intake and milk yield, averaging $25.3 \pm$ $0.97 \mathrm{~kg} / \mathrm{d}$ and $26.9 \pm 1.94 \mathrm{~kg} / \mathrm{d}$, respectively (means \pm standard error of the means). Milk fat and lactose concentrations were unaffected by treatments but milk protein concentration decreased in cows fed treatments with $30 \%$ low-fat DDGS compared with those fed treatments with $15 \%$ low-fat DDGS (3.49 vs. $3.40 \pm 0.12 \%$ ). Updated predictions from the Cornell-Penn-Miner Dairy model showed a decrease of $25 \mathrm{~g}$ of metabolizable protein Lys in cows fed treatments with 30\% low-fat DDGS. Compared with cows fed treatments with $15 \%$ low-fat DDGS, cows fed treatments with 30\% low-fat DDGS had a marked increase in extraction efficiency (49.4 vs. $61.4 \pm 2.51 \%)$ and a tendency to increase milk protein concentration (3.41 vs. $3.48 \pm 0.12 \%$ )
\end{abstract}

Received May 2, 2014.

Accepted June 24, 2014

${ }^{1}$ Current address: Grain States Soya Inc., West Point, NE 68788.

${ }^{2}$ Corresponding author: pkononoff2@unl.edu with RPL supplementation, which supported that Lys supply was inadequate. Despite differences observed in milk protein concentration, milk protein yield was similar across treatments and averaged $0.92 \pm 0.06 \mathrm{~kg} / \mathrm{d}$. Lack of response on arterial Lys concentration with RPL supplementation leads us to suspect that the RPL product delivered a lower amount of metabolizable Lys than expected. Based on extraction efficiencies, Lys, Arg, and Phe were the first 3 limiting AA across treatments. Supplementation of rumen-protected AA has the potential to be an effective nutritional strategy to supply limiting AA; however, accurate information on the bioavailability of the AA is needed.

Key words: dairy cow, low-fat distillers dried grains with solubles, amino acid, rumen-protected lysine, extraction efficiency

\section{INTRODUCTION}

Two attributes that hinder the use of distillers dried grains with solubles (DDGS) in dairy cattle diets are the unbalanced profile of AA compared with milk protein requirements and the high fat content. Insufficient supply of Lys (Carvalho et al., 2006; Kleinschmit et al., 2006) may decrease milk protein concentration, whereas increased production of biohydrogenation intermediates from linoleic acid (Leonardi et al., 2005; Hippen et al., 2010) may decrease milk fat concentration. Emergence of DDGS with reduced fat content and improved protein quality offers greater flexibility of inclusion of this coproduct in dairy rations (Mjoun et al., 2010b). Ethanol production facilities have added a centrifugation step that partially recovers fat from the condensed distillers solubles, producing low-fat DDGS, which are characterized by containing around half the fat concentration of conventional DDGS.

Milk protein score compares the most limiting AA in a protein supplement or diet relative to that same AA in milk protein (Schingoethe, 1996) and can be used to assess protein quality. Compared with the milk protein score of 0.32 for DDGS reported by Schingoethe (1996), the current milk protein score is around 
0.42 based on more recent AA composition of DDGS (Paz et al., 2013a) and milk (NRC, 2001). The latter means that DDGS have increased from containing 32 to $42 \%$ as much Lys as in milk protein. Despite this improvement in protein quality, as inclusion of low-fat DDGS increases in dairy diets, it is more likely that Lys supply will be of more concern than the risk of milk fat depression. In this scenario, supplementation of rumen-protected Lys (RPL) could be the most effective method to better match the Lys requirement for milk production and improve $\mathrm{N}$ efficiency. Technologies that protect Lys from rumen degradation have emerged (Wu et al., 2012) and RPL products are becoming increasingly available (Blauwiekel et al., 1997; Paz et al., 2013b). The objective of this study was to evaluate the effects of feeding different amounts of low-fat DG in diets with or without the supplementation of RPL on lactation responses and AA utilization. We hypothesized that if Lys supply limits milk protein, then supplementation with RPL should be beneficial in high inclusion rates of DDGS.

\section{MATERIALS AND METHODS}

\section{Animals, Diets, and Experimental Design}

Eight multiparous Holstein cows averaging $188 \pm 13$ DIM were assigned to a replicated $4 \times 4$ Latin square with a $2 \times 2$ factorial arrangement of treatments. Cows were randomly assigned to squares and squares differed in treatment sequences that were balanced for carryover effects. Experimental periods lasted $21 \mathrm{~d}$ and consisted of $18 \mathrm{~d}$ for treatment adaptation and $3 \mathrm{~d}$ for data and sample collection. Cows were housed in tie-stalls with continuous access to water, fed a TMR once daily at $0830 \mathrm{~h}$ at approximately $110 \%$ of anticipated intake, and milked twice daily at 0700 and $1900 \mathrm{~h}$ using a double-5 herringbone parlor (BouMatic LLC, Madison, WI). After each milking, cows were allowed to exercise in an outside lot for $1 \mathrm{~h}$. Animal care and experimental procedures were conducted according to the guidelines of the University of Nebraska-Lincoln Animal Care and Use Committee.

Cows were offered 1 of the 4 following dietary treatments: (1) 15\% low-fat DDGS (15DDGS), (2) 15DDGS plus RPL (15DDGSRPL), (3) 30\% low-fat DG (30DDGS), or (4) 30DDGS plus RPL (30DDGSRPL). The 2 basal treatments that contained low-fat DDGS at either 15 (15DDGS) or 30\% (30DDGS) of the DM (Table 1) were formulated using the CornellPenn-Miner (CPM) Dairy software (v3.0; Boston et al., 2000) to be isonitrogenous $(16.9 \% \mathrm{CP}$ ) and isocaloric $(\mathrm{ME}=2.63 \mathrm{Mcal} / \mathrm{kg})$. Based on CPM Dairy predictions, Lys was predicted to supply $6.00 \%$ of the
MP and meet $105 \%$ of the MP-Lys requirement in the 15DDGS diet and to supply $5.24 \%$ of the MP and meet $93 \%$ of the MP-Lys requirement in the 30DDGS diet. Supplementation of RPL (AminoShure-L; assayed LLys $=51.5 \%$; Balchem Encapsulates, New Hampton, $\mathrm{NY}$ ) to the 15DDGS and 30DDGS diets resulted in 2 additional treatments, 15DDGSRPL and 30DDGSRPL, respectively. Rumen-protected Lys was supplemented at $64 \mathrm{~g}$ via top-dressing evenly over the TMR at 0830 and $2030 \mathrm{~h}$ for a total of $128 \mathrm{~g}$ of RPL daily. The supplementation regimen was based on the times when cows returned to their respective stalls after milking and exercising. The total amount of RPL supplemented was expected to supply $42 \mathrm{~g}$ of MP-Lys. Smartamine M (Adisseo Inc., Antony, France) was added at a rate of $16 \mathrm{~g} / \mathrm{d}$ per cow to ensure that all diets provided sufficient amounts of MP-Met. Based on CPM Dairy predictions and taking into account the expected MP-Lys supplied by the RPL product, the Lys-to-Met ratios were $2.56: 1,3.22: 1,2.34: 1$, and $3.00: 1$ for the 15DDGS, 15DDGSRPL, 30DDGS, and 30DDGSRPL diets, respectively. As-fed diet composition was adjusted weekly to account for the DM variation of alfalfa and corn silages. Individual intake of the TMR, refusals, and milk yield were recorded daily during the entire experiment.

\section{Sampling Period Measurements}

From d 19 to 21 of each period, forages, low-fat DDGS, concentrates, and TMR were collected daily, refrigerated $\left(4^{\circ} \mathrm{C}\right)$, and composited at the end of each period. Composites of feeds and concentrates were divided into 2 subsamples. One subsample from each composite was dried for $48 \mathrm{~h}$ at $55^{\circ} \mathrm{C}$ in a forced-air oven, subsequently ground with a Wiley Mill (1-mm screen; Arthur H. Thomas Co., Philadelphia, PA). Ground samples were send to the Experimental Station Chemical Laboratories, University of Missouri-Columbia (Columbia) and analyzed for AA (AOAC International, 2006; method 982.30 E) using a Hitachi L-8800 AA analyzer (Hitachi Ltd., Tokyo, Japan). The remaining subsample from each composite was sent to Cumberland Valley Analytical Services Inc. (Hagerstown, MD) and analyzed for DM (AOAC International, 2000); N (Leco FP-528 Nitrogen Combustion Analyzer; Leco Corp., St. Joseph, MI); ADF (AOAC International, 2000; method 973.18); NDF (Van Soest et al., 1991); ether extract (AOAC International, 2006; method 2003.05); ash (AOAC International, 2000; method 942.05); Ca, P, $\mathrm{Mg}, \mathrm{K}, \mathrm{Na}, \mathrm{Fe}, \mathrm{Mn}, \mathrm{Zn}$, and $\mathrm{Cu}$ (AOAC International, 2000; method 985.01); and pH analysis (ensiled silages; Mettler DL12 Titrator; Mettler-Toledo Inc., Columbus, $\mathrm{OH})$. Chemical and AA compositions of the diets were calculated based on the analysis of the forages and 
Table 1. Ingredient composition of the basal treatments

\begin{tabular}{lcc}
\hline & \multicolumn{2}{c}{ Diet $^{1}$} \\
\cline { 2 - 3 } Ingredient, & 15DDGS & 30DDGS \\
\hline Corn silage & 29.7 & 29.7 \\
Brome hay & 8.33 & 8.33 \\
Alfalfa hay & 5.98 & 5.98 \\
Alfalfa silage & 4.97 & 4.97 \\
Ground corn & 25.0 & 17.8 \\
Low-fat DDGS & 15.0 & 30.0 \\
Soybean meal, & 7.83 & 0.00 \\
Smartamine M & 0.07 & 0.07 \\
Limestone & 1.72 & 1.72 \\
Sodium bicarbonate & 0.48 & 0.48 \\
Salt & 0.48 & 0.48 \\
Magnesium oxide & 0.25 & 0.25 \\
Trace mineral premix & 3.11 & 0.11 \\
Vitamin premix & & 0.11 \\
\hline
\end{tabular}

${ }^{1} 15$ DDGS $=$ diet containing $15 \%$ low-fat distillers dried grains with solubles (DDGS); 30DDGS = diet containing 30\% low-fat DDGS.

${ }^{2}$ Adisseo Inc. (Alpharetta, GA). Smartamine M was assumed to contain $75 \%$ Met equivalence with a bioavailability of $80 \%$.

${ }^{3}$ Contained $13.9 \%$ Ca, $0.03 \%$ P, $0.42 \% \mathrm{Mg}, 0.20 \% \mathrm{~K}, 4.20 \% \mathrm{~S}, 0.08 \%$ $\mathrm{Na}, 0.03 \% \mathrm{Cl}, 445 \mathrm{mg}$ of $\mathrm{Fe} / \mathrm{kg}, 60,021 \mathrm{mg}$ of $\mathrm{Zn} / \mathrm{kg}, 17,375 \mathrm{mg}$ of $\mathrm{Cu} /$ $\mathrm{kg}, 43,470 \mathrm{mg}$ of $\mathrm{Mn} / \mathrm{kg}, 287 \mathrm{mg}$ of Se $/ \mathrm{kg}, 527 \mathrm{mg}$ of $\mathrm{Co} / \mathrm{kg}$, and 870 $\mathrm{mg}$ of $\mathrm{I} / \mathrm{kg}$.

${ }^{4}$ Provided approximately $5,770 \mathrm{KIU}$ of vitamin $\mathrm{A} / \mathrm{kg}, 1,460 \mathrm{KIU}$ of vitamin $\mathrm{D} / \mathrm{kg}$, and $46,400 \mathrm{KIU}$ of vitamin $\mathrm{E} / \mathrm{kg}$.

concentrates and their respective proportions in the diets. Composites of the TMR were used to evaluate particle size using the Penn State Particle Separator (The Pennsylvania State University, University Park) as outlined by Heinrichs and Kononoff (2002) and a subsample was analyzed for DM $\left(48 \mathrm{~h} 55^{\circ} \mathrm{C}\right.$ oven $)$ to determine DMI by the cows.

From d 19 to 21, BW was measured and 10-mL milk samples were collected during the a.m. and p.m. milkings. Milk samples were stored at room temperature in a vial containing a 10 -mg preserving pellet (2-bromo2nitropropane-1,3-diol). Milk samples were analyzed for true protein, fat, and lactose by infrared spectroscopy (B200 Infrared Analyzer; Bentley Instruments Inc., Chaska, MN), MUN by a modified Berthelot reaction (ChemSpec 150 Analyzer; Bentley Instruments Inc.), and SCC using a flow cytometer laser (Somacount 500; Bentley Instruments Inc.) by Heart of America DHIA (Manhattan, KS). On d 21, BCS was measured by a single trained individual using a method similar to that of Wildman et al. (1982) but reported to the quarter point.

\section{Plasma AA}

On d 20 and 21, 2 sets of blood samples were collected via venipuncture of the coccygeal artery and subcutaneous abdominal vein from each cow at 1130 and $2330 \mathrm{~h}$ using $10-\mathrm{mL}$ evacuated tubes containing $\mathrm{K}_{2}$ EDTA (Becton Dickinson and Co., Rutherford, NJ). Samples were immediately placed in an ice bath after collection and then centrifuged within 45 min at 3,300 $\times g$ for $20 \mathrm{~min}$ at room temperature. For each sample, an aliquot of $4 \mathrm{~mL}$ of plasma was deproteinized (4 vol of plasma were vortexed with 1 vol of $15 \%$ sulfosalicylic acid) and then centrifuged at 3,300 $\times g$ for 20 min at room temperature. Subsequently, the supernatant was collected and $0.30-\mathrm{mL}$ aliquots were placed into Nunc CryoTube vials (Nalge Nunc International, Roskilde, Denmark) and stored at $-20^{\circ} \mathrm{C}$. Samples from the $2 \mathrm{~d}$ of collection were pooled, resulting in 1 pair of arterial and venous samples for each cow at the $1130 \mathrm{~h}$ sampling time and 1 pair of arterial and venous samples for each cow at the $2330 \mathrm{~h}$ sampling time. Then samples were taken to the laboratory and stored at $-80^{\circ} \mathrm{C}$ until analyzed for plasma free AA (Fekkes, 1996) using a Hitachi L-8800 AA analyzer by the Experimental Station Chemical Laboratories, University of MissouriColumbia (Columbia). Plasma concentrations ( $\mu \mathrm{g} /$ $\mathrm{mL}$ ) of AA were adjusted to account for the use of $15 \%$ sulfosalicylic acid. The concentrations of each AA in arterial and venous plasma were used to estimate extraction efficiency as follows: [arteriovenous (AV) difference/arterial concentration] $\times 100$.

\section{Statistical Analysis}

Analyses of lactation responses and intake data were performed on collection period means (last $3 \mathrm{~d}$ ) from each cow. Data were analyzed using PROC MIXED of SAS (SAS Institute, 2008) based on the following model:

$$
\mathrm{Y}_{\mathrm{ijklm}}=\mu+\pi_{\mathrm{i}}+\beta_{\mathrm{j}}+\rho_{\mathrm{k}: \mathrm{i}}+\gamma_{1}+\lambda_{\mathrm{m}}+\varepsilon_{\mathrm{ijklm}},
$$

where $Y_{\mathrm{ijklm}}=$ dependent variable, $\mu=$ overall mean, $\pi_{\mathrm{i}}=$ random effect of square $(1 \mathrm{df}), \beta_{\mathrm{j}}=$ random effect of period $(3 \mathrm{df}), \rho_{\mathrm{k}: \mathrm{i}}=$ random effect of cow within square $(6 \mathrm{df}), \gamma_{1}=$ fixed effect of inclusion rate of lowfat DDGS (1 df), $\lambda_{\mathrm{m}}=$ fixed effect of RPL supplementation $(1 \mathrm{df})$, and $\varepsilon_{\mathrm{ijklm}}=$ residual error $(19 \mathrm{df})$. The interaction $\gamma \times \lambda$ was removed from the model when $P>0.10$. Significance was declared at $P \leq 0.05$ and trends at $0.05<P \leq 0.10$.

Plasma concentrations of AA and extraction efficiencies were analyzed based on the following model:

$$
\mathrm{Y}_{\mathrm{ijklmn}}=\mu+\pi_{\mathrm{i}}+\beta_{\mathrm{j}}+\rho_{\mathrm{k}: \mathrm{i}}+\gamma_{\mathrm{l}}+\lambda_{\mathrm{m}}+\tau_{\mathrm{n}}+\varepsilon_{\mathrm{ijklmn}},
$$

where $Y_{i j k l m n}=$ dependent variable, $\mu=$ overall mean, $\pi_{\mathrm{i}}=$ random effect of square $(1 \mathrm{df}), \beta_{\mathrm{j}}=$ random effect 
of period $(3 \mathrm{df}), \rho_{\mathrm{k}: \mathrm{i}}=$ random effect of cow within square $(6 \mathrm{df}), \gamma_{1}=$ fixed effect of inclusion rate of lowfat DDGS (1 df), $\lambda_{m}=$ fixed effect of RPL supplementation $(1 \mathrm{df}), \tau_{\mathrm{n}}=$ fixed effect of time $(1 \mathrm{df})$, and $\varepsilon_{\mathrm{ijklmn}}=$ residual error $(50 \mathrm{df})$. Interaction terms were removed from the model when $P>0.10$. Significance was declared at $P \leq 0.05$ and trends at $0.05<P \leq$ 0.10 .

\section{RESULTS AND DISCUSSION}

Coproducts are mainly used to decrease the cost of a diet without compromising milk yield and components. In doing so, several studies support the inclusion of DDGS in dairy diets without negatively affecting milk production or composition, as reported in the review of Paz et al. (2013a). Diets should provide adequate amounts of both MP and MP-Lys to meet requirements for milk protein synthesis and should not contain excessive amounts of carbohydrates and PUFA to avoid milk fat depression. The current trend in the production of livestock feed from ethanol plants removes fat from the coproduct stream and has resulted in low-fat DDGS. The lower fat content of this coproduct may be a key to increase its inclusion, with a decreased risk of milk fat depression; however, Lys supply remains a concern. Diets may contain DDGS at $20 \%$ of the DM and result in comparable (Paz et al., 2013a) or enhanced (Paz et al., 2013b) milk protein responses compared with the control diet; however, Lys supply could be deficient at greater inclusion rates. In the current experiment, lowfat DDGS was included at 15 or $30 \%$ of the DM.

\section{Feed and Diet Chemical Compositions}

The chemical compositions of feeds and concentrates are shown in Table 2. Chemical compositions of forages were similar to other reported values (NRC, 2001). Low-fat DDGS used in this experiment contained around half the fat content $(6.35 \%$ of $\mathrm{DM})$ compared with conventional DDGS (12.0\% of DM; Paz et al., 2013a). Inclusion of low-fat DDGS in the concentrates was increased at the expense of corn and soybean meal and, as expected, concentrates contained a similar concentration of CP (21.8\% of DM) but starch and NFC concentrations decreased and NDF concentration increased. The AA compositions of feeds and concentrates are shown in Table 3. Compared with published values for conventional DDGS (NRC, 2001), low-fat DDGS had similar total EAA (TEAA) concentration; however, specifically for Lys and Leu, concentrations were 33.5 and $13.7 \%$ greater, respectively. As expected, the Lys concentration in the 30DDGS concentrate was less compared with the 15DDGS concentrate, as low-fat
DDGS replaced soybean meal, which is greater in Lys concentration.

The chemical compositions and particle size distributions of the basal treatments are shown in Table 4 . As anticipated, diets were similar in $\mathrm{CP}$ concentration (16.6\% of DM) and the differences in NDF and NFC concentrations reflected the concentrate compositions, as diets contained the same forage mixture and inclusion. The reduced fat concentration in low-fat DDGS allowed the increase of this feed from 15 to $30 \%$ of the diet DM without a substantial increase in fat concentration (3.48 and $3.84 \%$ of DM for the 15DDGS and 30DDGS diets, respectively). The proportion of particles retained on the $>19-\mathrm{mm}$ and $8-\mathrm{mm}$ screens of the Penn State Particle Separator were similar across treatments, whereas the proportion of particles retained on the 1.18-mm and bottom pan $(<1.18-\mathrm{mm})$ differed. Particles retained on the $1.18-\mathrm{mm}$ screen were greater in the 15DDGS diet and particles retained on the bottom pan were greater in the 30DDGS diet. Distillers dried grains with solubles are characterized by a mean particle size smaller than $1.18 \mathrm{~mm}$ (Kelzer et al., 2010); thus, observed differences in particle size distribution were expected. Compared with recommendations (Heinrichs and Kononoff, 2002), particles retained were lesser for the 8-mm screen and greater for the bottom pan across treatments.

The AA composition of the basal treatments is shown in Table 5. Differences in the AA composition of the concentrates were reflected in the treatments. Specifically, an increase in the inclusion of low-fat DDGS from 15 to $30 \%$ of the diet DM resulted in an increase in the concentration of Ala (13.4\%), Cys (19.2\%), Leu (14.2\%), Met (11.7\%), and Pro (15.2\%) and a decrease in the concentrations of $\operatorname{Arg}(11.1 \%)$, Asp (10.1\%), and Lys (15.2\%). Similar observations have been previously reported as DDGS inclusion increases in the diet (Paz et al., 2013b). Despite differences in specific EAA concentrations, the TEAA concentration was similar for the treatments and averaged $34.7 \%$ of CP.

\section{Animal Responses}

Effects of treatments on intake, milk yield and composition, BW, and BCS are shown in Table 6. Across animal responses, interactions between inclusion rate of low-fat DDGS and RPL supplementation were not significant $(P \geq 0.30)$; thus, only main effects are discussed. Neither inclusion rate of low-fat DDGS nor RPL supplementation affected DMI. Similar DMI by the cows at both inclusion rates of low-fat DDGS was expected because the proportions of forage and concentrate were identical across treatments, thus promoting similar effects on rumen fill (Mertens, 1987). No effect 
Table 2. Chemical composition of feeds and concentrates $^{1}$

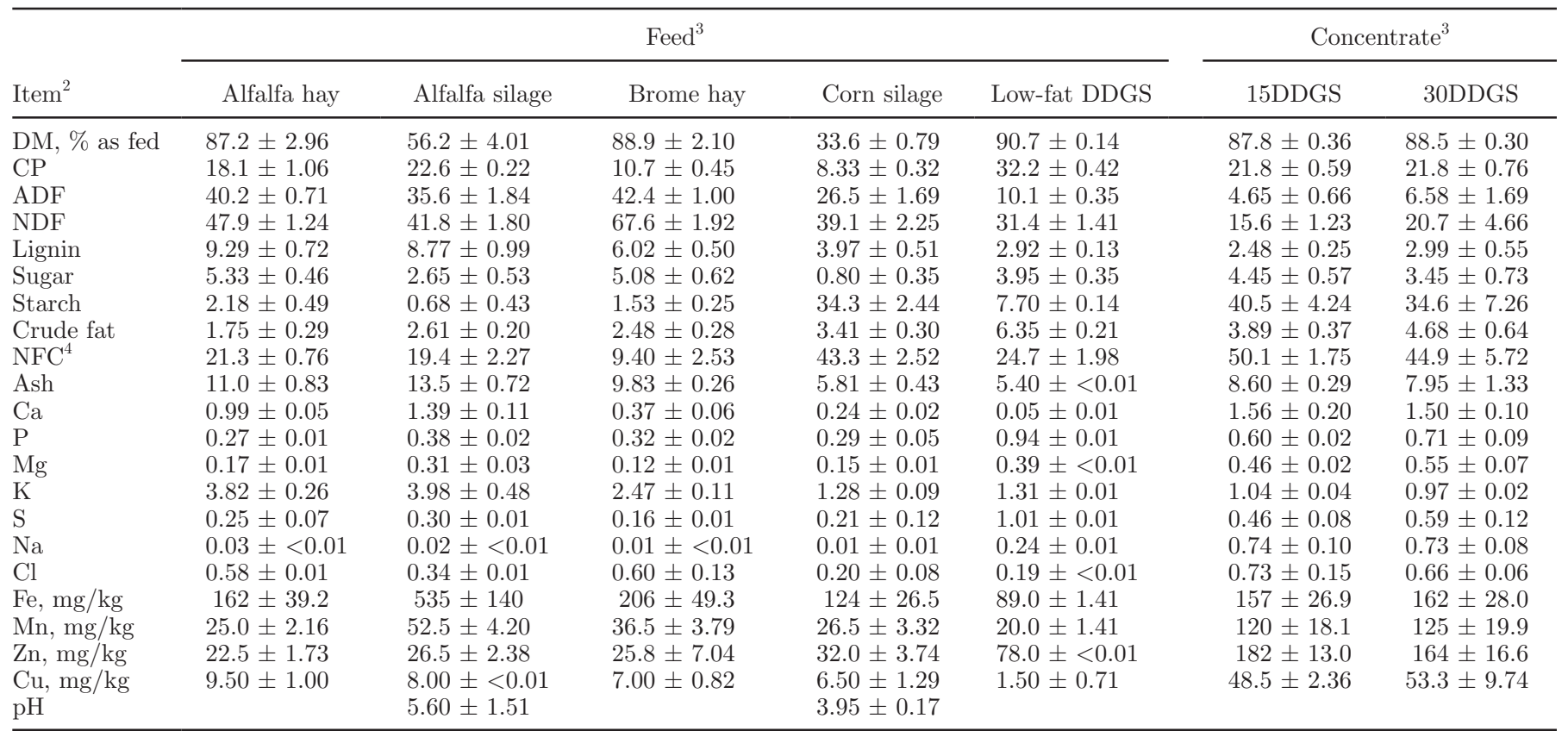

${ }^{1}$ Values $(\mathrm{n}=4)$ are expressed as mean \pm SD.

${ }^{2}$ Values are expressed in percentage of DM, unless otherwise noted.

${ }^{3}$ DDGS $=$ distillers dried grains with solubles; 15DDGS = diet containing 15\% low-fat DDGS; 30DDGS = diet containing 30\% low-fat DDGS.

${ }^{4}$ Nonfiber carbohydrates, calculated by difference: $100-(\% \mathrm{NDF}+\% \mathrm{CP}+\%$ fat $+\%$ ash $)(\mathrm{NRC}, 2001)$.

Table 3. Amino acid composition of feeds and concentrates ${ }^{1}$

\begin{tabular}{|c|c|c|c|c|c|c|c|}
\hline $\begin{array}{l}\mathrm{AA}, \\
\% \text { of } \mathrm{CP}\end{array}$ & \multicolumn{5}{|c|}{ Feed $^{2}$} & \multicolumn{2}{|c|}{ Concentrate $^{2}$} \\
\hline Arg & $3.04 \pm 0.28$ & $2.30 \pm 0.33$ & $3.27 \pm 0.60$ & $1.23 \pm 0.14$ & $4.27 \pm 0.14$ & $4.95 \pm 0.49$ & $4.14 \pm 0.19$ \\
\hline Ile & $3.15 \pm 0.28$ & $3.55 \pm 0.44$ & $2.66 \pm 0.51$ & $3.07 \pm 0.14$ & $3.75 \pm 0.07$ & $3.60 \pm 0.32$ & $3.50 \pm 0.21$ \\
\hline Leu & $5.13 \pm 0.46$ & $5.54 \pm 0.72$ & $5.22 \pm 0.91$ & $7.61 \pm 0.38$ & $10.9 \pm 0.21$ & $8.84 \pm 0.56$ & $10.4 \pm 0.59$ \\
\hline Lys & $3.51 \pm 0.31$ & $3.41 \pm 0.50$ & $3.03 \pm 0.46$ & $1.41 \pm 0.11$ & $2.99 \pm 0.08$ & $3.82 \pm 0.35$ & $2.93 \pm 0.21$ \\
\hline Trp & $0.89 \pm 0.18$ & $0.58 \pm 0.11$ & $0.54 \pm 0.05$ & $0.48 \pm 0.02$ & $0.81 \pm 0.01$ & $0.96 \pm 0.13$ & $0.83 \pm 0.05$ \\
\hline Val & $4.52 \pm 0.50$ & $4.70 \pm 0.55$ & $3.72 \pm 0.62$ & $4.51 \pm 0.19$ & $5.06 \pm 0.09$ & $4.68 \pm 0.37$ & $4.88 \pm 0.23$ \\
\hline TEAA $^{3}$ & $29.0 \pm 2.49$ & $29.2 \pm 3.30$ & $26.9 \pm 4.59$ & $26.3 \pm 1.27$ & $40.0 \pm 0.86$ & $38.5 \pm 2.86$ & $39.0 \pm 1.93$ \\
\hline Ala & $3.87 \pm 0.35$ & $4.56 \pm 0.40$ & $4.28 \pm 0.73$ & $9.95 \pm 0.49$ & $6.57 \pm 0.13$ & $5.29 \pm 0.31$ & $6.41 \pm 0.36$ \\
\hline Asp & $10.7 \pm 1.13$ & $9.45 \pm 1.11$ & $5.83 \pm 1.01$ & $3.27 \pm 0.32$ & $5.93 \pm 0.01$ & $7.34 \pm 0.78$ & $6.00 \pm 0.29$ \\
\hline Cys & $0.87 \pm 0.09$ & $0.74 \pm 0.08$ & $0.73 \pm 0.13$ & $0.78 \pm 0.08$ & $1.92 \pm 0.05$ & $1.52 \pm 0.12$ & $1.84 \pm 0.08$ \\
\hline TNEAA $^{4}$ & $38.3 \pm 3.61$ & $35.2 \pm 3.60$ & $28.6 \pm 4.87$ & $35.1 \pm 1.48$ & $46.2 \pm 0.94$ & $44.9 \pm 3.13$ & $46.4 \pm 2.35$ \\
\hline
\end{tabular}

${ }^{1}$ Values $(\mathrm{n}=4)$ are expressed as mean \pm SD.

${ }^{2}$ DDGS $=$ distillers dried grains with solubles; 15DDGS = diet containing $15 \%$ low-fat DDGS; 30DDGS = diet containing 30\% low-fat DDGS.

${ }^{3}$ Total EAA (Arg, His, Ile, Leu, Lys, Met, Phe, Thr, Trp, and Val).

${ }^{4}$ Total NEAA (Ala, Asp, Cys, Glu, Gly, Pro, Ser, and Tyr). 
Table 4. Chemical composition and particle size distribution of the basal treatments ${ }^{1}$

\begin{tabular}{|c|c|c|}
\hline \multirow[b]{2}{*}{ Item } & \multicolumn{2}{|c|}{ Diet $^{2}$} \\
\hline & 15DDGS & 30DDGS \\
\hline \multicolumn{3}{|l|}{ Composition $^{3}$} \\
\hline DM, $\%$ as fed & $58.2 \pm 0.99$ & $58.4 \pm 1.02$ \\
\hline $\mathrm{CP}$ & $16.6 \pm 0.30$ & $16.7 \pm 0.37$ \\
\hline $\mathrm{RDP}^{3} \%$ of $\mathrm{CP}$ & 63.1 & 61.4 \\
\hline $\mathrm{RUP}^{3} \%$ of $\mathrm{CP}$ & 36.9 & 38.6 \\
\hline $\mathrm{ADF}$ & $17.8 \pm 0.55$ & $18.9 \pm 1.28$ \\
\hline $\mathrm{NDF}$ & $29.9 \pm 1.16$ & $32.8 \pm 3.13$ \\
\hline Lignin & $3.94 \pm 0.25$ & $4.20 \pm 0.33$ \\
\hline Sugar & $3.53 \pm 0.37$ & $2.87 \pm 0.44$ \\
\hline Starch & $30.8 \pm 2.26$ & $28.1 \pm 3.66$ \\
\hline Crude fat & $3.48 \pm 0.16$ & $3.84 \pm 0.41$ \\
\hline NFC & $41.7 \pm 1.60$ & $38.7 \pm 3.66$ \\
\hline Ash & $8.28 \pm 0.19$ & $7.93 \pm 0.55$ \\
\hline $\mathrm{Ca}$ & $1.06 \pm 0.13$ & $1.00 \pm 0.05$ \\
\hline $\mathrm{P}$ & $0.45 \pm 0.02$ & $0.51 \pm 0.04$ \\
\hline $\mathrm{ME},{ }^{4} \mathrm{Mcal} / \mathrm{kg}$ & 2.56 & 2.55 \\
\hline MP-Lys, ${ }^{4} \mathrm{~g} / \mathrm{d}$ & 176 & 151 \\
\hline MP allowable milk, ${ }^{4} \mathrm{~kg} / \mathrm{d}$ & 38 & 36 \\
\hline \multicolumn{3}{|l|}{ Particle size distribution ${ }^{5}$} \\
\hline$>19.0 \mathrm{~mm}$ & $5.89 \pm 1.53$ & $6.83 \pm 1.44$ \\
\hline $8.0-19.0 \mathrm{~mm}$ & $25.1 \pm 2.80$ & $25.6 \pm 2.79$ \\
\hline $1.18-8.0 \mathrm{~mm}$ & $32.4 \pm 3.54$ & $26.6 \pm 2.64$ \\
\hline$<1.18 \mathrm{~mm}$ & $36.6 \pm 5.17$ & $41.0 \pm 4.63$ \\
\hline
\end{tabular}

${ }^{1}$ Values $(\mathrm{n}=4)$ are expressed as mean $\pm \mathrm{SD}$.

${ }^{2} 15$ DDGS $=$ diet containing $15 \%$ low-fat distillers dried grains with solubles (DDGS); 30DDGS = diet containing 30\% low-fat DDGS.

${ }^{3}$ Values are expressed in percentage of DM, unless otherwise noted.

${ }^{4}$ Estimations are based on CPM Dairy software (v3.0; Boston et al., 2000) using assayed feed analyses and observed DMI.

${ }^{5}$ Proportion (as fed) of TMR retained on each screen of the Penn State Particle Separator (The Pennsylvania State University, University Park).

of RPL supplementation on DMI is in agreement with other studies (Blauwiekel et al., 1997; Robinson et al., 2011). Milk yield was not affected by inclusion rate of low-fat DDGS and averaged (mean \pm SEM) $26.9 \pm$ $1.94 \mathrm{~kg} / \mathrm{d}$. We did not expect a response in milk yield with PRL supplementation, as it is more likely to affect milk protein percentage (NRC, 2001). Inclusion rate of low-fat DDGS $(P=0.01)$ and RPL supplementation $(P=0.09)$ affected milk protein concentration. Specifically, cows fed treatments with $30 \%$ low-fat DDGS had lower milk protein concentration compared with those fed treatments with 15\% low-fat DDGS. Inclusion of DDGS at $30 \%$ of the diet DM has been previously noted to compromise milk protein concentration and this response was attributed to a deficiency in Lys supply (Mjoun et al., 2010c). It is important to note that Mjoun et al. (2010c) observed a quadratic response in milk protein concentration as inclusion of low-fat DDGS increased from 15 to $30 \%$ of the diet DM; however, milk protein concentration was similar in cows fed the control and 30\% low-fat DDGS diets. In the present study, RPL supplementation tended $(P=0.09)$ to increase
Table 5. Amino acid composition of the basal treatments ${ }^{1}$

\begin{tabular}{lcc}
\hline & \multicolumn{2}{c}{ Diet $^{2}$} \\
\cline { 2 - 3 }$\%$ of CP & 15 DDGS & 30 DDGS \\
\hline Arg & $3.89 \pm 0.37$ & $3.46 \pm 0.11$ \\
His & $1.90 \pm 0.12$ & $2.00 \pm 0.07$ \\
Ile & $3.38 \pm 0.23$ & $3.37 \pm 0.13$ \\
Leu & $7.93 \pm 0.37$ & $9.06 \pm 0.37$ \\
Lys & $3.28 \pm 0.24$ & $2.78 \pm 0.15$ \\
Met & $1.62 \pm 0.18$ & $1.81 \pm 0.22$ \\
Phe & $3.85 \pm 0.24$ & $3.98 \pm 0.13$ \\
Thr & $3.05 \pm 0.16$ & $3.17 \pm 0.10$ \\
Trp & $0.82 \pm 0.11$ & $0.75 \pm 0.03$ \\
Val & $4.54 \pm 0.24$ & $4.73 \pm 0.15$ \\
TEAA & $34.3 \pm 2.08$ & $35.1 \pm 1.15$ \\
Ala & $5.76 \pm 0.18$ & $6.53 \pm 0.22$ \\
Asp & $6.82 \pm 0.61$ & $6.13 \pm 0.22$ \\
Cys & $1.25 \pm 0.08$ & $1.49 \pm 0.05$ \\
Glu & $11.8 \pm 0.85$ & $11.9 \pm 0.55$ \\
Gly & $3.56 \pm 0.21$ & $3.64 \pm 0.10$ \\
Pro & $5.99 \pm 0.20$ & $6.90 \pm 0.28$ \\
Ser & $3.03 \pm 0.13$ & $3.18 \pm 0.14$ \\
Tyr & $2.61 \pm 0.17$ & $2.73 \pm 0.09$ \\
TNEAA & $40.8 \pm 2.28$ & $42.5 \pm 1.51$ \\
\hline
\end{tabular}

${ }^{1}$ Values $(n=4)$ are expressed as mean \pm SD.

${ }^{2} 15$ DDGS $=$ diet containing $15 \%$ low-fat distillers dried grains with solubles (DDGS); 30DDGS = diet containing 30\% low-fat DDGS.

${ }^{3}$ Total EAA (Arg, His, Ile, Leu, Lys, Met, Phe, Thr, Trp, and Val).

${ }^{4}$ Total NEAA (Ala, Asp, Cys, Glu, Gly, Pro, Ser, and Tyr).

milk protein concentration, which supported that Lys supply limited milk protein response in cows fed treatments with 30\% low-fat DDGS. Despite the previously described effects on milk protein concentration, milk protein yield was similar across treatments. Milk fat concentration and yield were not affected by inclusion rate of low-fat DDGS or RPL supplementation. Compared with conventional DDGS, inclusion of low-fat DDGS results in a reduced load of PUFA that can give rise to ruminal biohydrogenation intermediates associated with milk fat depression (Hippen et al., 2010); thus, high inclusion of this coproduct may represent lower risk of milk fat depression. The increasing effect of inclusion rate of low-fat DDGS $(P=0.02)$ on feed conversion is most likely an artifact of the numerical differences for both milk yield and DMI, as inclusion rate of low-fat DDGS did not affect these responses individually. Across treatments, BW, BW change, BCS, and BCS change did not differ, which suggests that treatments adequately met the energy requirements of the cows.

The effects of treatments on AA intakes are shown in Table 7. Overall, differences in AA profile of treatments were reflected in AA intakes. Cows fed treatments with $30 \%$ low-fat DDGS had greater intakes of Ala $(P<$ $0.01)$, Cys $(P<0.01)$, Leu $(P<0.01)$, Met $(P=0.03)$, and Pro $(P<0.01)$ and lower intakes of $\operatorname{Arg}(P<0.01)$, Asp $(P<0.01)$, Ile $(P=0.09)$, Lys $(P<0.01)$, and Trp 
Table 6. Effects of treatments on intake, milk yield and composition, BW, and BCS

\begin{tabular}{|c|c|c|c|c|c|c|c|}
\hline \multirow[b]{2}{*}{ Item } & \multicolumn{2}{|c|}{ DDGS $^{1}$} & \multicolumn{2}{|c|}{$\mathrm{RPL}^{2}$} & \multirow[b]{2}{*}{ SEM } & \multicolumn{2}{|c|}{$P$-value ${ }^{3}$} \\
\hline & $15 \%$ & $30 \%$ & Without & With & & DDGS & RPL \\
\hline DMI, $\mathrm{kg} / \mathrm{d}$ & 25.8 & 24.7 & 25.4 & 25.1 & 0.97 & 0.11 & 0.59 \\
\hline Milk yield, $\mathrm{kg} / \mathrm{d}$ & 26.3 & 27.4 & 27.1 & 26.6 & 1.94 & 0.23 & 0.64 \\
\hline Protein, \% & 3.49 & 3.40 & 3.41 & 3.48 & 0.12 & 0.01 & 0.09 \\
\hline Protein yield, $\mathrm{kg} / \mathrm{d}$ & 0.91 & 0.93 & 0.92 & 0.92 & 0.06 & 0.55 & 0.92 \\
\hline Fat, $\%$ & 3.70 & 3.73 & 3.70 & 3.73 & 0.24 & 0.52 & 0.62 \\
\hline Fat yield, $\mathrm{kg} / \mathrm{d}$ & 0.97 & 1.02 & 1.00 & 0.99 & 0.08 & 0.17 & 0.69 \\
\hline Lactose, $\%$ & 4.58 & 4.60 & 4.60 & 4.59 & 0.08 & 0.44 & 0.70 \\
\hline $\mathrm{SNF}, \%$ & 8.94 & 8.87 & 8.88 & 8.93 & 0.20 & 0.19 & 0.35 \\
\hline MUN, mg/dL & 13.3 & 13.2 & 13.3 & 13.3 & 1.43 & 0.74 & 0.78 \\
\hline $3.5 \% \mathrm{FCM}^{4}, \mathrm{~kg} / \mathrm{d}$ & 27.1 & 28.4 & 28.0 & 27.6 & 2.04 & 0.18 & 0.67 \\
\hline $\mathrm{FC}^{5}$ & 1.01 & 1.12 & 1.07 & 1.06 & 0.05 & 0.02 & 0.68 \\
\hline $\mathrm{BW}, \mathrm{kg}$ & 748 & 748 & 750 & 746 & 54.8 & 0.89 & 0.31 \\
\hline BW change, $\mathrm{kg}$ & 16.2 & 12.8 & 14.8 & 14.2 & 4.68 & 0.59 & 0.92 \\
\hline $\mathrm{BCS}^{6}$ & 3.11 & 3.09 & 3.11 & 3.09 & 0.05 & 0.68 & 0.68 \\
\hline BCS change $^{7}$ & 0.08 & 0.05 & 0.08 & 0.05 & 0.04 & 0.52 & 0.52 \\
\hline
\end{tabular}

${ }^{1}$ Inclusion rate of low-fat distillers dried grains with solubles (DDGS) at either 15 or $30 \%$ of the diet DM.

${ }^{2} \mathrm{RPL}=$ rumen-protected Lys.

${ }^{3}$ Interactions DDGS $\times$ RPL $(P \geq 0.30)$ were removed from the model.

${ }^{4} \mathrm{FCM}=[$ milk fat $(\mathrm{kg} / \mathrm{d}) \times 16.218]+[$ milk yield $(\mathrm{kg} / \mathrm{d}) \times 0.4324]$ (Tyrrell and Reid, 1965).

${ }^{5}$ Feed conversion $(\mathrm{FC})=$ milk yield $/ \mathrm{DMI}$.

${ }^{6}$ Cow BCS was determined on a 1 to 5 scale according to Wildman et al. (1982).

${ }^{7}$ Based on the entire period.

Table 7. Effects of treatments on AA intake

\begin{tabular}{|c|c|c|c|c|c|c|c|}
\hline \multirow[b]{2}{*}{$\mathrm{AA}, \mathrm{g} / \mathrm{d}$} & \multicolumn{2}{|c|}{$\mathrm{DDGS}^{1}$} & \multicolumn{2}{|c|}{$\mathrm{RPL}^{2}$} & \multirow[b]{2}{*}{ SEM } & \multicolumn{2}{|c|}{$P$-value ${ }^{3}$} \\
\hline & $15 \%$ & $30 \%$ & Without & With & & DDGS & RPL \\
\hline Arg & 167.3 & 142.6 & 155.8 & 154.1 & 7.79 & $<0.01$ & 0.70 \\
\hline His & 81.7 & 82.2 & 82.6 & 81.4 & 3.54 & 0.79 & 0.55 \\
\hline Ile & 145.3 & 138.9 & 143.1 & 141.1 & 6.17 & 0.09 & 0.60 \\
\hline Leu & 340.4 & 373.0 & 359.5 & 353.8 & 14.0 & $<0.01$ & 0.52 \\
\hline Lys & 172.9 & 146.4 & 128.4 & 190.9 & 5.00 & $<0.01$ & $<0.01$ \\
\hline Met & 69.5 & 74.7 & 72.5 & 71.8 & 5.38 & 0.03 & 0.76 \\
\hline Phe & 165.6 & 164.0 & 165.9 & 163.7 & 7.10 & 0.70 & 0.60 \\
\hline Thr & 131.1 & 130.5 & 131.7 & 129.9 & 5.91 & 0.85 & 0.56 \\
\hline Trp & 35.3 & 30.8 & 33.2 & 32.9 & 2.17 & $<0.01$ & 0.76 \\
\hline Val & 195.2 & 194.7 & 196.4 & 193.5 & 8.04 & 0.91 & 0.56 \\
\hline $\mathrm{TEAA}^{4}$ & 1,504 & 1,477 & 1,469 & 1,513 & 63.5 & 0.47 & 0.24 \\
\hline $\mathrm{BCAA}^{5}$ & 680.9 & 706.5 & 698.9 & 688.5 & 28.1 & 0.15 & 0.54 \\
\hline Ala & 246.9 & 268.8 & 260.0 & 255.8 & 8.95 & $<0.01$ & 0.51 \\
\hline Asp & 293.7 & 252.2 & 274.4 & 271.5 & 15.3 & $<0.01$ & 0.69 \\
\hline Cys & 53.7 & 61.2 & 57.9 & 57.0 & 2.82 & $<0.01$ & 0.49 \\
\hline Glu & 508.7 & 490.5 & 502.9 & 496.4 & 24.1 & 0.17 & 0.62 \\
\hline Gly & 153.2 & 149.7 & 152.5 & 150.4 & 6.57 & 0.35 & 0.57 \\
\hline Pro & 256.7 & 283.9 & 272.7 & 267.9 & 9.26 & $<0.01$ & 0.47 \\
\hline Ser & 130.2 & 130.9 & 131.5 & 129.6 & 6.11 & 0.81 & 0.56 \\
\hline Tyr & 112.3 & 112.4 & 113.2 & 111.5 & 4.99 & 0.98 & 0.56 \\
\hline TNEAA $^{6}$ & $1,755.4$ & $1,749.6$ & $1,765.1$ & $1,740.1$ & 76.7 & 0.89 & 0.57 \\
\hline
\end{tabular}

${ }^{1}$ Inclusion rate of low-fat distillers dried grains with solubles (DDGS) at either 15 or $30 \%$ of the diet DM.

${ }^{2} \mathrm{RPL}=$ rumen-protected Lys.

${ }^{3}$ Interactions DDGS $\times$ RPL $(P \geq 0.38)$ were removed from the model.

${ }^{4}$ Total EAA (Arg, His, Ile, Leu, Lys, Met, Phe, Thr, Trp, and Val).

${ }^{5}$ Branched-chain AA (Ile, Leu, and Val).

${ }^{6}$ Total NEAA (Ala, Asp, Cys, Glu, Gly, Pro, Ser, and Tyr). 
Table 8. Effects of treatments on plasma concentrations of AA and urea from the coccygeal artery

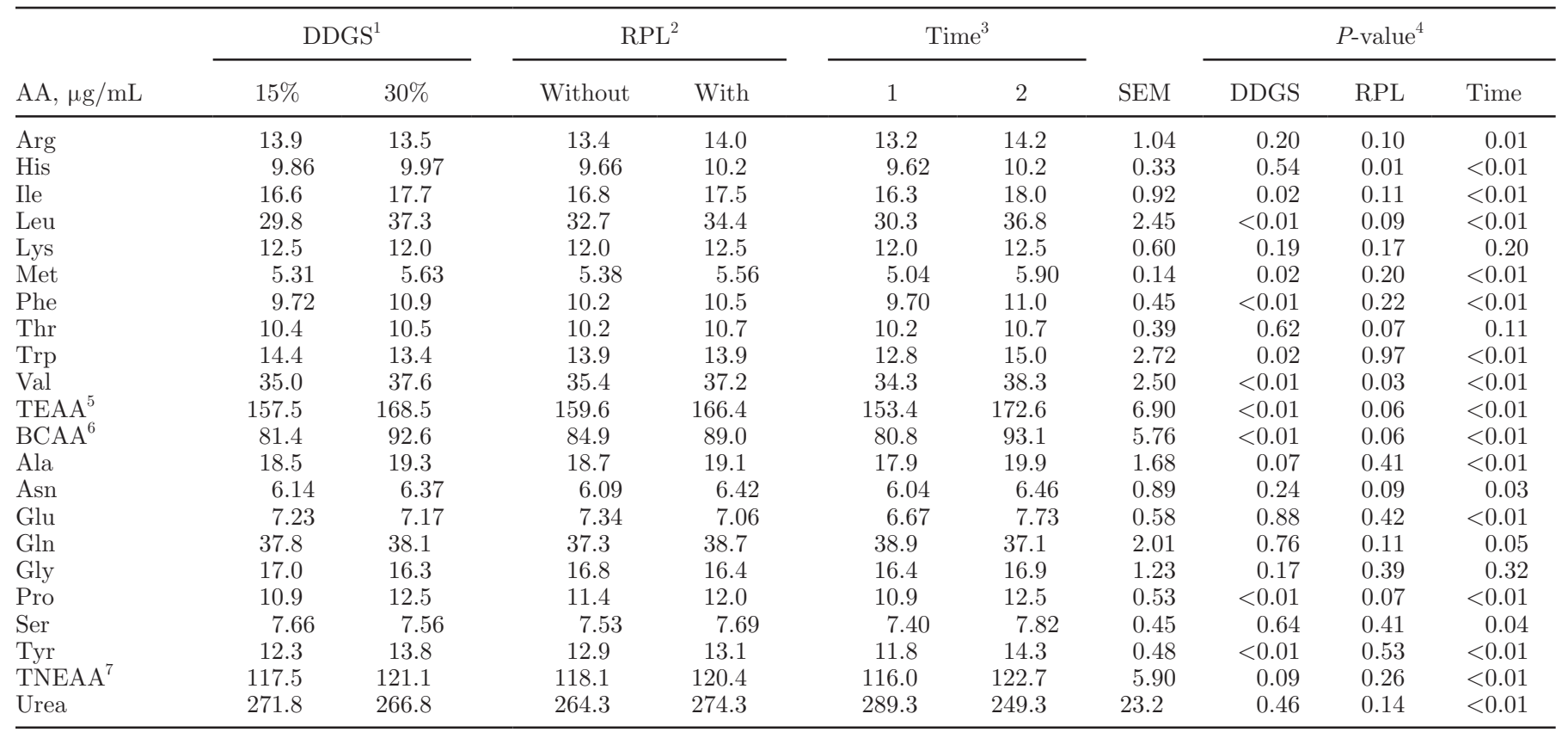

${ }^{1}$ Inclusion rate of low-fat distillers dried grains with solubles (DDGS) at either 15 or $30 \%$ of the diet DM.

${ }^{2} \mathrm{RPL}=$ rumen-protected Lys.

${ }^{3}$ Sampling times: $1=1130 \mathrm{~h}$ and $2=2330 \mathrm{~h}$.

${ }^{4}$ Interactions DDGS $\times \operatorname{RPL}(P \geq 0.17)$ DDGS $\times$ time $(P \geq 0.27)$, and RPL $\times$ time $(P \geq 0.13)$ were removed from the model.

${ }^{5}$ Total EAA (Arg, His, Ile, Leu, Lys, Met, Phe, Thr, Trp, and Val).

${ }^{6}$ Branched-chain AA (Ile, Leu, and Val).

${ }^{7}$ Total NEAA (Ala, Asn, Glu, Gln, Gly, Pro, Ser, and Tyr).

$(P<0.01)$ compared with cows fed treatments with $15 \%$ low-fat DDGS. As designed, RPL supplementation increased Lys intake $(P<0.01)$ and had no effect on the intakes of the remaining AA.

\section{Plasma AA}

Effects of treatments on plasma concentrations of AA and urea from the coccygeal artery are shown in Table 8. Generally, differences in plasma concentrations of AA were reflective of differences in treatments AA compositions caused by the 2 inclusion rates of low-fat DDGS. Despite the marked decrease in MP-Lys supply as low-fat DDGS increased from 15 to $30 \%$ of the diet DM (176 vs. $151 \mathrm{~g} / \mathrm{d}$, respectively), only a numerical decrease in arterial Lys concentration was observed. In previous work (Paz et al., 2013b), a reduction of $12 \%$ in the arterial Lys concentration was observed as conventional DDGS increased from 10 to $20 \%$ of the diet DM. For the remaining AA, arterial concentrations of Ala $(P=0.07)$, Ile $(P=0.02)$, Leu $(P<0.01)$, Met $(P=0.02)$, Phe $(P<0.01)$, Pro $(P<0.01)$, Tyr $(P<$ $0.01)$, and Val $(P<0.01)$ increased, whereas arterial concentrations of $\operatorname{Trp}(P=0.02)$ decreased. Overall, arterial concentration of TEAA was greater $(P<0.01)$ and total NEAA (TNEAA) tended to be greater $(P=0.09)$ for cows fed diets containing $30 \%$ low-fat DDGS compared with those fed $15 \%$ low-fat DDGS. It is important to note that large amounts of RPL were supplemented in this study. This was done to provide the opportunity to observe a response in milk protein with increased Lys supply. However, RPL supplementation only caused a numerical increase in arterial Lys concentration and tended $(P=0.06)$ to increase arterial TEAA concentration. Despite the positive effect on milk protein concentration, no effect on arterial Lys concentration with the high RPL supplementation regimen used in this study leads us to suspect that the RPL product delivered a lower amount of MP-Lys than expected. No effects on plasma urea concentration and MUN support the latter idea. A similar observation was previously reported (Paz et al., 2013b) when feeding a version of the RPL product that contained 38\% L-Lys.

Similar to the current, Guinard and Rulquin (1994) observed positive effects on milk protein concentration and arterial TEAA concentration when L-Lys $\mathrm{HCl}$ was duodenally infused in cows fed a Lys-deficient diet. The authors speculated that arterial TEAA concentration increased because of decreased oxidation of AA and this improved $\mathrm{N}$ utilization when Lys was infused. 
Table 9. Effects of treatments on plasma concentrations of AA from the subcutaneous abdominal vein

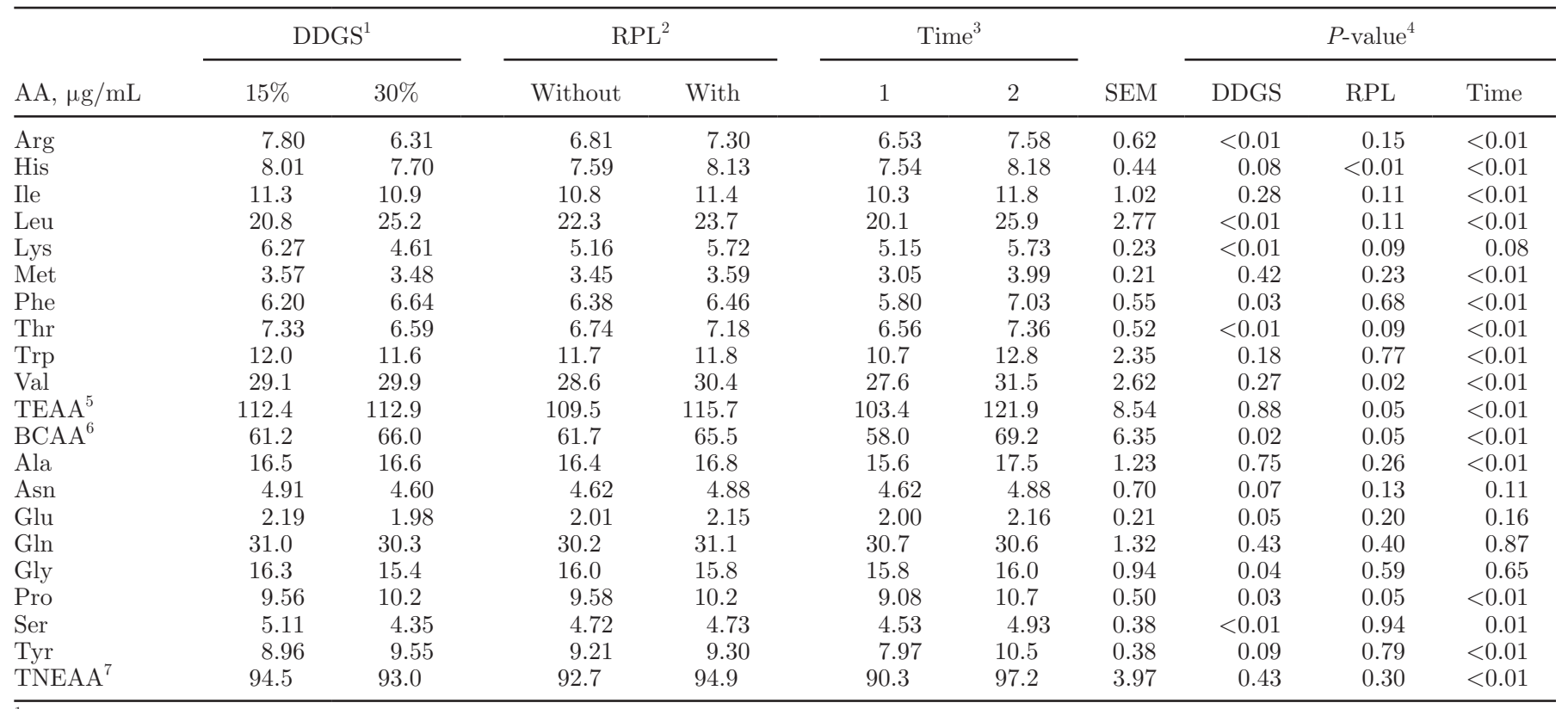

${ }^{1}$ Inclusion rate of low-fat distillers dried grains with solubles (DDGS) at either 15 or $30 \%$ of the diet DM.

${ }^{2} \mathrm{RPL}=$ rumen-protected Lys.

${ }^{3}$ Sampling times: $1=1130 \mathrm{~h}$ and $2=2330 \mathrm{~h}$.

${ }^{4}$ Interactions DDGS $\times \operatorname{RPL}(P \geq 0.17)$, DDGS $\times$ time $(P \geq 0.12)$, and RPL $\times$ time $(P \geq 0.19)$ were removed from the model.

${ }^{5}$ Total EAA (Arg, His, Ile, Leu, Lys, Met, Phe, Thr, Trp, and Val).

${ }^{6}$ Branched-chain AA (Ile, Leu, and Val).

${ }^{7}$ Total NEAA (Ala, Asn, Glu, Gln, Gly, Pro, Ser, and Tyr).

Contrarily, Schwab et al. (1992) observed an increase in milk protein concentration but a decrease in arterial TEAA concentration when Met plus Lys were duodenally infused and suggested that the decrease in arterial TEAA concentration reflected an increase in the removal of AA, which aided in the positive milk protein concentration response. The difference between the previously discussed infusion studies could be related to the different blood sampling regimens. Generally, arterial concentration of EAA and NEAA were greater at 2330 than $1130 \mathrm{~h}$ in the present study. Because of limited blood-sampling times, it is unclear if the observed differences in arterial AA concentrations were attributed to the diurnal pattern of arterial AA concentrations.

Effects of treatments on plasma concentrations of AA from the subcutaneous vein are shown in Table 9. Similar to observed arterial concentration, cows fed treatments with $30 \%$ low-fat DDGS had greater concentrations of Leu $(P<0.01)$, Phe $(P=0.03)$, Pro $(P=0.03)$, and Tyr $(P=0.09)$ compared with those fed treatments with $15 \%$ low-fat DDGS. Additionally, venous concentrations of $\operatorname{Arg}(P<0.01)$, Asn $(P=$ $0.07)$, Glu $(P=0.05)$, Gly $(P=0.04)$, His $(P=0.08)$, Lys $(P<0.01)$, Ser $(P<0.01)$, and Thr $(P<0.01)$ decreased in cows fed treatments with $30 \%$ low-fat
DDGS. Effect of RPL supplementation on venous AA concentrations reflected those observed in arterial AA concentrations, except for venous Lys concentration, which tended $(P=0.09)$ to increase with RPL supplementation. Effects of venous AA concentrations because of time were similar to those observed for arterial concentrations.

Effects of treatments on AV differences of AA are shown in Table 10. Generally, AV differences were affected by inclusion rate of low-fat DDGS but not by RPL supplementation and time. Overall, cows fed treatments with $30 \%$ low-fat DDGS had greater AV differences of TEAA, BCAA, and TNEAA, which matched arterial concentrations. Despite no difference in arterial concentration, AV difference of Lys increased in cows fed treatments with $30 \%$ low-fat DDGS. Arterial Lys concentration has been observed to influence mammary gland metabolism by having a positive effect on AV differences of Lys (Mjoun et al., 2010c) until potentially reaching a plateau (Guinard and Rulquin, 1994). In the present study, increased uptake of Lys, the EAA with the lowest supply, seemed to have promoted an increase in the uptakes of the remaining EAA.

Determination of extraction efficiency of AA has been used as a tool to rank limiting AA (Mulrooney et 
Table 10. Effects of treatments on arteriovenous differences of AA

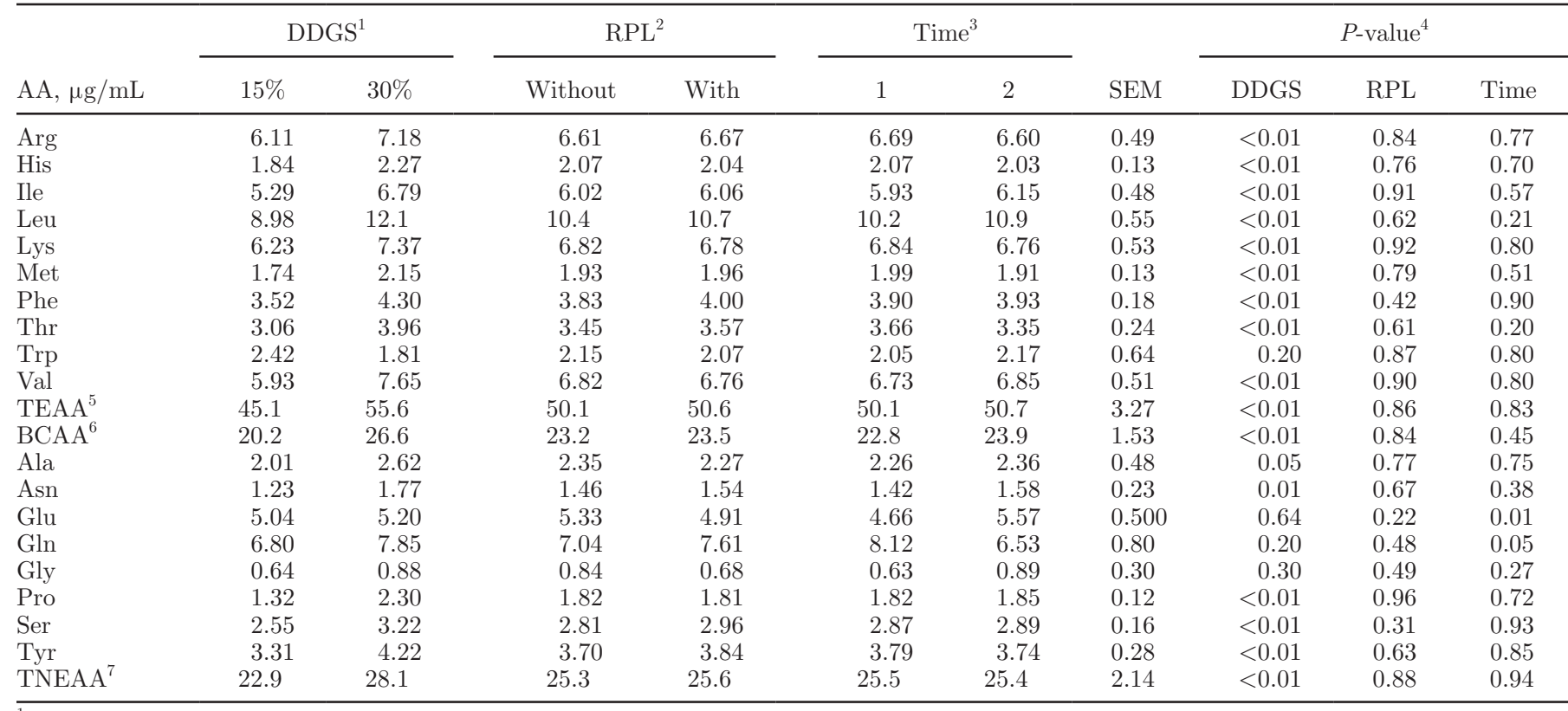

${ }^{1}$ Inclusion rate of low-fat distillers dried grains with solubles (DDGS) at either 15 or $30 \%$ of the diet DM.

${ }^{2} \mathrm{RPL}=$ rumen-protected Lys.

${ }^{3}$ Sampling times: $1=1130 \mathrm{~h}$ and $2=2330 \mathrm{~h}$.

${ }^{4}$ Interactions DDGS $\times$ RPL $(P \geq 0.30)$, DDGS $\times$ time $(P \geq 0.13)$, and RPL $\times$ time $(P \geq 0.13)$ were removed from the model.

${ }^{5}$ Total EAA (Arg, His, Ile, Leu, Lys, Met, Phe, Thr, Trp, and Val).

${ }^{6}$ Branched-chain AA (Ile, Leu, and Val).

${ }^{7}$ Total NEAA (Ala, Asn, Glu, Gln, Gly, Pro, Ser, and Tyr).

al., 2009; Mjoun et al., 2010c). Using this method, AA are ranked in descending order, which means that the AA with the highest extraction efficiency is the first limiting AA. Extraction efficiency has been suggested to be a more accurate method to estimate limiting AA because it accounts for the total AA needs (synthesis and catabolism) of the mammary gland (Mulrooney et al., 2009) and does not include the error associated with the measurement of mammary blood flow that is problematic in methods such as transfer efficiency and uptake-to-output ratio (Nichols et al., 1998). Effects of treatments on extraction efficiencies of AA are shown in Table 11. Extraction efficiencies of all EAA were greater, except for Trp, which was similar in cows fed treatments with $30 \%$ low-fat DDGS to cows fed treatments with $15 \%$ low-fat DDGS. Extraction efficiency of TNEAA was also greater $(P=0.01)$ in cows fed treatments with $30 \%$ low-fat DDGS. For Lys, extraction efficiency increased $24.3 \%$ in cows fed treatments with $30 \%$ low-fat DDGS. The latter better reflected the difference in Lys supply between the treatments than arterial Lys concentration. Despite an increase in extraction efficiency of Lys, Mjoun et al. (2010c) also observed a decrease in milk protein concentration as DDGS increased up to $30 \%$ of the diet DM, which showed that Lys supply limited milk protein. In the current study, RPL supplementation did not affect extraction efficiency of Lys. Extraction efficiency of TEAA was affected by time, being greater $(P=0.04)$ at $1130 \mathrm{~h}$ compared with $2330 \mathrm{~h}$, which was related to a lower arterial TEAA concentration at $1130 \mathrm{~h}$, as AV differences were similar at both times. Extraction efficiencies of NEAA were not taken into account in the ranking of limiting AA, as these can be synthesized within the body and had not been shown to limit milk or milk protein yield. At both inclusion rates of low-fat DDGS, Lys, Arg, and Phe were the first 3 limiting AA and this was not affected by RPL supplementation or time. Others have reported the first 3 limiting AA to be Lys, Met, and Phe when feeding low-fat DDGS at $20 \%$ of the diet DM (Mjoun et al., 2010a) or Lys, Arg, and Met when feeding low-fat DG at 30\% of the diet DM (Mjoun et al., 2010c). That Met was not among the first 3 limiting AA in the present study was not surprising, as all treatments were supplemented with rumen-protected Met.

\section{CONCLUSIONS}

Inclusion rate of low-fat DDGS and RPL supplementation had no effect on DMI, milk yield, and milk fat and lactose concentrations. Milk protein concentration 
Table 11. Effects of treatments on extraction efficiencies of AA

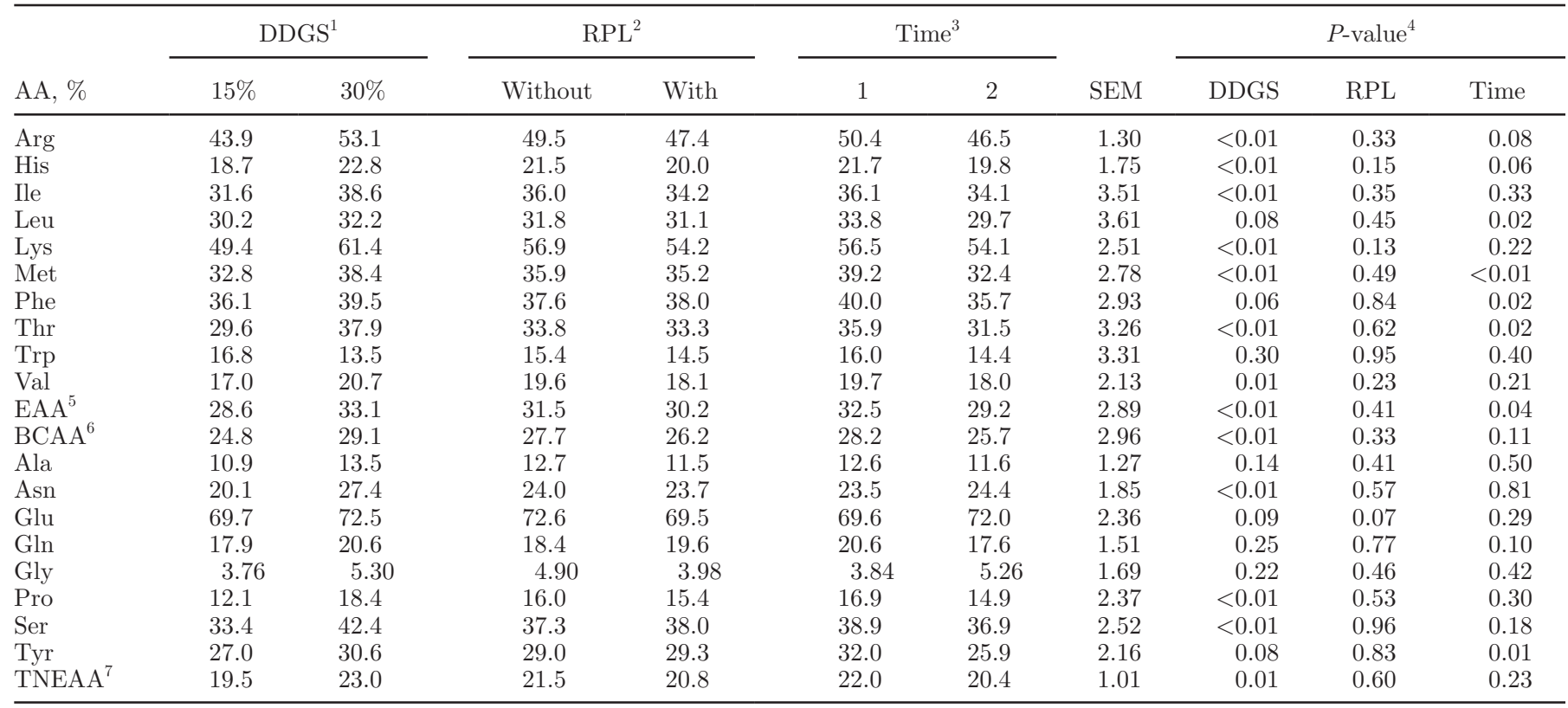

${ }^{1}$ Inclusion rate of low-fat distillers dried grains with solubles (DDGS) at either 15 or $30 \%$ of the diet DM.

${ }^{2} \mathrm{RPL}=$ rumen-protected Lys.

${ }^{3}$ Sampling times: $1=1130 \mathrm{~h}$ and $2=2330 \mathrm{~h}$.

${ }^{4}$ Interactions DDGS $\times \operatorname{RPL}(P \geq 0.35)$, DDGS $\times$ time $(P \geq 0.15)$, and RPL $\times$ time $(P \geq 0.27)$ were removed from the model.

${ }^{5}$ Total EAA (Arg, His, Ile, Leu, Lys, Met, Phe, Thr, Trp, and Val).

${ }^{6}$ Branched-chain AA (Ile, Leu, and Val).

${ }^{7}$ Total NEAA (Ala, Asn, Glu, Gln, Gly, Pro, Ser, and Tyr).

decreased in cows fed increased amounts of DDGS. The increased inclusion of low-fat DDGS resulted in greater extraction efficiency of Lys and RPL supplementation tended to increase milk protein concentration, which suggests that in dairy diets, the supply of MP-Lys may be manipulated through diet formulation. Practically, RPL supplementation can be used as an effective nutritional strategy to increase MP-Lys; however, accurate information on the bioavailability of the rumen-protected nutrient is needed.

\section{REFERENCES}

AOAC International. 2000. Official Methods of Analysis. 17th ed. AOAC International, Gaithersburg, MD.

AOAC International. 2006. Official Methods of Analysis. 18th ed. AOAC International, Gaithersburg, MD.

Blauwiekel, R., S. Xu, J. H. Harrison, K. A. Loney, R. E. Riley, and M. C. Calhoun. 1997. Effect of whole cottonseed, gossypol, and ruminally protected lysine supplementation on milk yield and composition. J. Dairy Sci. 80:1358-1365.

Boston, R. C., D. G. Fox, C. J. Sniffen, R. Janczewski, R. Munson, and W. Chalupa. 2000. The conversion of a scientific model describing dairy cow nutrition and production to an industry tool: The CPM Dairy project. Pages 361-377 in Modelling Nutrient Utilization in Farm Animals. J. P. McNamara, J. France, and D. Beever, ed. CABI Publishing, Oxford, UK.

Carvalho, L. P. F., A. R. J. Cabrita, R. J. Dewhurst, T. E. J. Vicente, Z. M. C. Lopes, and A. J. M. Fonseca. 2006. Evaluation of palm kernel meal and corn distillers grains in corn silage-based diets for lactating dairy cows. J. Dairy Sci. 89:2705-2715.

Fekkes, D. 1996. State-of-the-art of high-performance liquid chromatographic analysis of amino acids in physiological samples. J. Chromatogr. B Biomed. Appl. 682:3-22.

Guinard, J., and H. Rulquin. 1994. Effects of graded amounts of duodenal infusions of lysine on the mammary uptake of major milk precursors in dairy cows. J. Dairy Sci. 77:3565-3576.

Heinrichs, A. J., and P. J. Kononoff. 2002. Evaluating particle size of forages and TMRs using the New Penn State Forage Particle Separator. Tech. Bull. DAS 02-42. Pennsylvania State Univ., College Agric. Sci., Cooperative Ext., University Park.

Hippen, A. R., D. J. Schingoethe, K. F. Kalscheur, P. L. Linke, D. R. Rennich, M. M. Abdelqader, and I. Yoon. 2010. Saccharomyces cerevisiae fermentation product in dairy cow diets containing dried distillers grains plus solubles. J. Dairy Sci. 93:2661-2669.

Kelzer, J. M., P. J. Kononoff, L. O. Tedeschi, T. C. Jenkins, K. Karges, and M. L. Gibson. 2010. Evaluation of protein fractionation and ruminal and intestinal digestibility of corn milling co-products. J. Dairy Sci. 93:2803-2815.

Kleinschmit, D. H., D. J. Schingoethe, K. F. Kalscheur, and A. R. Hippen. 2006. Evaluation of various sources of corn dried distillers grains plus solubles for lactating dairy cattle. J. Dairy Sci. 89:4784-4794.

Leonardi, C., S. Bertics, and L. E. Armentano. 2005. Effect of increasing oil from distillers grains or corn oil on lactation performance. J. Dairy Sci. 88:2820-2827.

Mertens, D. R. 1987. Predicting intake and digestibility using mathematical models of ruminal function. J. Anim. Sci. 64:1548-1558.

Mjoun, K., K. F. Kalscheur, A. R. Hippen, and D. J. Schingoethe. 2010a. Performance and amino acid utilization of early lactation dairy cows fed regular or reduced-fat dried distillers grains with solubles. J. Dairy Sci. 93:3176-3191. 
Mjoun, K., K. F. Kalscheur, A. R. Hippen, and D. J. Schingoethe 2010b. Ruminal degradability and intestinal digestibility of protein and amino acids in soybean and corn distillers grains products. J. Dairy Sci. 93:4144-4154.

Mjoun, K., K. F. Kalscheur, A. R. Hippen, D. J. Schingoethe, and D. E. Little. 2010c. Lactation performance and amino acid utilization of cows fed increasing amounts of reduced-fat dried distillers grains with solubles. J. Dairy Sci. 93:288-303.

Mulrooney, C. N., D. J. Schingoethe, K. F. Kalscheur, and A. R. Hippen. 2009. Canola meal replacing distillers grains with solubles for lactating dairy cows. J. Dairy Sci. 92:5669-5676.

Nichols, J. R., D. J. Schingoethe, H. A. Maiga, M. J. Brouk, and M. S. Piepenbrink. 1998. Evaluation of corn distillers grains and ruminally protected lysine and methionine for lactating dairy cows. J. Dairy Sci. 81:482-491.

NRC. 2001. Nutrient Requirements of Dairy Cattle. 7th rev. ed. Natl. Acad. Press, Washington, DC.

Paz, H. A., E. Castillo-Lopez, H. A. Ramirez-Ramirez, D. A. Christensen, T. J. Klopfenstein, and P. J. Kononoff. 2013a. Invited review: Ethanol co-products for dairy cows: There goes our starch . . . now what? Can. J. Anim. Sci. 93:407-425.

Paz, H. A., M. J. de Veth, R. S. Ordway, and P. J. Kononoff. 2013b. Evaluation of rumen-protected lysine supplementation to lactating dairy cows consuming increasing amounts of distillers dried grains with solubles. J. Dairy Sci. 96:7210-7222.
Robinson, P. H., N. Swanepoel, I. Shinzato, and S. O. Juchem. 2011. Productive responses of lactating dairy cattle to supplementing high levels of ruminally protected lysine using a rumen protection technology. Anim. Feed Sci. Technol. 168:30-41.

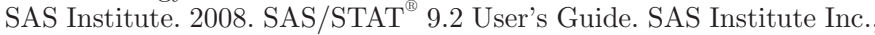
Cary, NC.

Schingoethe, D. J. 1996. Balancing the amino acid needs of the dairy cow. Anim. Feed Sci. Technol. 60:153-160.

Schwab, C. G., C. K. Bozak, N. L. Whitehouse, and M. M. A. Mesbah. 1992. Amino acid limitation and flow to duodenum at four stages of lactation. 1. Sequence of lysine and methionine limitation. J. Dairy Sci. 75:3486-3502.

Tyrrell, H. F., and J. T. Reid. 1965. Prediction of the energy value of cow's milk. J. Dairy Sci. 48:1215-1223.

Van Soest, P. J., J. B. Robertson, and B. A. Lewis. 1991. Methods for dietary fiber, neutral detergent fiber, and nonstarch polysaccharides in relation to animal nutrition. J. Dairy Sci. 74:3583-3597.

Wildman, E. E., G. M. Jones, P. E. Wagner, R. L. Boman, H. F. Troutt Jr., and T. N. Lesch. 1982. A dairy cow body condition scoring system and its relationship to selected production characteristics. J. Dairy Sci. 65:495-501.

Wu, Z., J. K. Bernard, R. B. Eggleston, and T. C. Jenkins. 2012 Ruminal escape and intestinal digestibility of ruminally protected lysine supplements differing in oleic acid and lysine concentrations. J. Dairy Sci. 95:2680-2684. 